Nordisk Tidsskrift for Kriminalvidenskab 2010

\title{
DEN NORDISKE RETSBEVIDSTHEDSUNDERSØGELSE
}

Af professor Flemming Balvig, professor Helgi Gunnlaugsson, doktorand Kristina Jerre, førsteamanuensis Leif Petter Olaussen og professor Henrik THAM

In 2009, a comprehensive comparative study of citizens' attitudes towards punishment was conducted in the five Nordic countries. In each country three kinds of attitudinal data were gathered. General attitudes to punishment were explored in a nationwide telephone interview. A postal survey to a random sample of citizens was used to investigate penal attitudes in six relatively serious cases. In an effort to compare citizens ' penal attitudes with the actual level of punishment, a panel of judges evaluated the six cases and suggested what the punishment would be if brought before the court. Finally, participants in a number of focus groups in Copenhagen, Oslo, Reykjavik and Stockholm answered the questionnaire used in the postal survey. Then the focus group participants watched a short mock trial film of court proceedings of one of the cases included in the questionnaire, and immediately afterwards answered a questionnaire about punishment for the accused. After one hour's discussion of punishment for the accused the focus group members answered a new questionnaire about punishment for him. The findings in Denmark, Iceland, Norway and Sweden were very much the same. (Data for Finland has not yet been analysed). Generally, a majority of citizens think that punishment is too lenient, especially for violence, and suggest more use of imprisonment. However, when asked to suggest a punishment for each of the six concrete cases, a majority suggest a punishment that is more lenient than the actual level of punishment. The studies also demonstrate that citizens underestimate the actual level of punishment. This explains why they, when asked general questions, complain that punishments are not stiff enough.*

\section{Innledning}

Undersøkelsene som det blir gjort rede for her, ble tatt initiativ til av Leif Petter Olaussen og er gjennomført som en komparativ undersøkelse i de fem nordiske land Danmark, Finland, Island, Norge og Sverige i 2009 av en prosjektgruppe som har bestått av Flemming Balvig, Janne Kivivuori, Helgi Gunnlaugsson, Leif Petter Olaussen og Henrik Tham. Undersøkelsene ble mulige fordi Nordisk Samarbeids-

\footnotetext{
* Title in English: Attitudes towards Punishment in the Nordic Countries. Original in Danish, Norwegian and Swedish.
} 
råd for Kriminologi bevilget 100.000 Euro som bidrag til undersøkelser i Finland, Island, Norge og Sverige, der undersøkelsene i tillegg er finansiert av ulike nasjonale institusjoner. Det danske justisministerium har finansiert alle danske undersøkelser. Vi takker så mye alle som har bidratt til at undersøkelsene lot seg realisere.

Det metodiske opplegg av undersøkelsene er det samme som ble benyttet av Balvig (2006). Dette blir gjort det rede for i nest pkt. De øvrige deler er skrevet av de som har foretatt analysene av de nasjonale datamaterialer og sto for presentasjonene på konferansen i København 19. august.

\section{Metodisk opplegg ${ }^{1}$}

Følelser og holdninger til sociale fænomener varierer med den grad af viden og nærhed, man har til dem. Når vidensniveauet er minimalt og fjernheden maksimal, bliver det forhåndsforestillinger og forventninger - "billeder" - der reageres ud fra. Holdninger og følelser kommer her til primært at sige noget om personen og dennes situation. Med større viden og større nærhed får holdninger og følelser i højere grad karakter af komplekse beslutninger. Følelserne bliver så at sige "fornuftige". Forhåndsforestillinger er her ikke længere enerådende. Der sker afvejninger af ikke blot flere karakteristika ved det sociale fænomen, men typisk også af modstridende informationer og under anvendelse af flere og til dels andre kriterier/formål.

Det er meningsløst at tale om nogle holdninger som mere rigtige eller sande end andre. Påstanden her er alene, at holdningerne kan variere med viden om og nærhed til et socialt fænomen, og at man følgelig bør have disse parametre med i en undersøgelse.

I den nordiske retsbevidsthedsundersøgelse har man med bl.a. disse overvejelser som baggrund dels villet afdække befolkningernes viden om og kendskab til, hvordan der straffes, og dels holdningerne til hvordan der straffes med udgangspunkt i forskellige grader og typer af viden og nærhed, jf. tabel 2.1.

Tabel 2.1. De gennemførte undersøgelser.

\begin{tabular}{|l|l|}
\hline EMNE & UNDERSøGELSER \\
\hline Stikord & Telefonsurveys \\
\hline Skriftlige sagsresuméer & Postenqueter + Fokusgrupper \\
\hline Filmede retssager & Fokusgrupper \\
\hline Retspraksis & Dommerpaneler \\
\hline
\end{tabular}

For det første har vi villet aflæse befolkningernes holdning, når det, de får forelagt, blot er visse generelle stikord såsom "vold", "fængsel" osv. - med fri, ube- 
grænset og individuel tilgang til selv at bestemme, hvad det er, man forestiller sig ved "vold", "fængsel" osv. F.eks. ved at stille befolkningen det nærmest klassiske spørgsmål: "Synes du, at straffene her i landet gennemgående er passende, for strenge eller for milde?" Telefonsurveys med tilsigtet repræsentative udsnit af de enkelte landes befolkninger 18-74 år er anvendt som metode til at afdække sådanne generelle holdninger. Der er dog ikke blevet gennemført telefonsurveys i Finland.

For det andet har vi ville aflæse, hvordan befolkningerne synes, der burde straffes, når de kort skriftligt blev informeret om de forskellige straffemuligheders formelle karakter, og herefter skulle være dommere i skriftligt opsummerede sager (knapt 1 A4-side pr. sag, i alt 6 sager; for Danmarks vedkommende 7 sager samt yderligere 7 sager i 2006). Bl.a. med det sigte at give de enkelte svarpersoner så god tid som muligt til at sætte sig ind i sagerne og strafmulighederne og overveje deres svar på egne præmisser er denne del af undersøgelserne foretaget i form af tilsigtet repræsentative postenqueter omfattende de enkelte landes befolkninger 18-74 år.

Endelig har vi så for det tredje - og det er det mest originale og principielt set mest interessante ved de gennemførte undersøgelser - været interesseret $i$ at aflæse, hvordan befolkningerne ville dømme, når det, de skulle dømme ud fra, var overværelse af en filmet retssag - dog uden afsluttende procedure, for ikke at afsløre retspraksis. Det er et udvalg (4 sager; for Danmarks vedkommende yderligere 4 sager i 2006) de samme sager, der her ligger til grund, som vi har anvendt ved skriftligt opsummerede retssager. Den enkelte sag er derefter spillet og filmet med en dommer fra det virkelige liv som dommer og ligeså med hensyn til forsvarer og anklager. Rollerne som vidner og tiltalte er blevet varetaget af professionelle skuespillere. Manuskripterne er udarbejdet i Danmark (i 2006 og 2009), hvor også retssagerne er spillet og opført i et retssagslignende rum. ${ }^{2}$ De samme film er så anvendt $i$ de andre nordiske lande, enten dubbede eller med undertekster. Tilsigtet repræsentative udsnit af de nordiske befolkninger 18-74 år har - opdelt i grupper bestående af gennemsnitligt omkring 10 deltagere - fået forevist filmene og er i 3 tempi blevet udbedt deres holdninger til, hvordan de personligt ville dømme: Inden de så retssagen (sagen resumeret skriftligt), umiddelbart efter at have set den filmede retssag og efter at have diskuteret den med andre i gruppen ("voteret"). Hver film er blevet forevist for 3 aldersopdelte fokusgrupper, dvs. hver sag er set og bedømt af omkring 30 personer. Fokusgruppeundersøgelserne er ikke blevet gennemført i Finland.

De 4 sager, der er blevet vist som filmede retssager i alle de nordiske lande, bortset fra Finland, drejer sig om gadevold, voldtægt, røveri og narkotikasmugling. De 2 yderligere sager, der alene er bedømt i postenqueterne, drejer sig om partnervold og økonomisk kriminalitet. ${ }^{3}$ 
Vi har haft brug for at få et bud på, hvordan der faktisk straffes i de sager, vi beskriver, dvs. domstolsprasis. Denne ikke ganske nemme eller entydige opgave har vi i hver af landene haft dommerpaneler, bestående af et antal byretsdommere og/eller byretspræsidenter, til at varetage. Som også forventet ud fra sagsudvælgelsen har retspraksis for de fleste af sagernes vedkommende i samtlige lande vist sig at være en kortere eller længere fængselsstraf. Sagerne repræsenterer således den relativt alvorlige del af kriminalitetsspektret.

Tabel 2.2. Svarprocenter i de gennemførte undersøgelser.

\begin{tabular}{|c|c|c|c|c|c|c|c|c|c|}
\hline \multirow[b]{2}{*}{$\AA \mathrm{Ar}$} & \multirow[b]{2}{*}{ Land } & \multicolumn{3}{|c|}{ Telefonsurveys } & \multicolumn{3}{|c|}{ Postenqueter } & \multicolumn{2}{|c|}{ Fokusgrupper } \\
\hline & & $\begin{array}{l}\text { Popu- } \\
\text { lation }\end{array}$ & $\begin{array}{l}\text { Besva- } \\
\text { relser }\end{array}$ & $\begin{array}{c}\text { Svar- } \\
\text { procent }\end{array}$ & $\begin{array}{l}\text { Popu- } \\
\text { lation }\end{array}$ & $\begin{array}{l}\text { Besva- } \\
\text { relser }\end{array}$ & $\begin{array}{c}\text { Svar- } \\
\text { procent }\end{array}$ & $\begin{array}{c}\text { Antal } \\
\text { grupper }\end{array}$ & $\begin{array}{c}\text { Del- } \\
\text { tager- } \\
\text { antal }\end{array}$ \\
\hline 2006 & \multirow{2}{*}{ DK } & 2.288 & 1.000 & $44 \%$ & 2.800 & 1.364 & $49 \%$ & 12 & 116 \\
\hline $2009-10$ & & 4.392 & 2.000 & $46 \%$ & 3.200 & 1.317 & $41 \%$ & 12 & 125 \\
\hline 2009 & NO & 9.339 & 1.001 & $11 \%$ & 3.000 & 935 & $31 \%$ & 12 & 116 \\
\hline 2009 & SE & 4.679 & 1.013 & $22 \%$ & 3.000 & 1.057 & $35 \%$ & 12 & 119 \\
\hline 2009 & FI & \multicolumn{3}{|c|}{$W_{1}$} & 3.000 & 936 & $31 \%$ & & \\
\hline $2009-10$ & IS & 1.000 & 652 & $65 \%$ & 3.000 & 1.055 & $35 \%$ & 12 & 106 \\
\hline
\end{tabular}

Det rammer alle undersøgelser og desværre også videnskabelige, at det bliver sværere og sværere at opnå høje svarprocenter, jf. tabel 2.2. Ved de gennemførte telefonsurveys er svarprocenterne meget lave i Sverige, og især i Norge. Ved postenqueterne er svarprocenterne noget højere i Danmark end i de andre lande, måske på grund af at de her blev gennemført i regi af et velrenommeret videnskabeligt institut, mens det i de andre nordiske lande er kommercielle bureauer, der har stået bag. Der foreligger ikke det nødvendige grundlag for at opgøre svarprocenter for fokusgruppeundersøgelserne. Eventuelle skævheder i de opnåede besvarelser sammenholdt med populationerne ved de forskellige undersøgelser er søgt rettet op gennem vanlige vægtningsmetoder.

Vi har gerne villet vide, ikke blot hvordan befolkningen ville dømme i en bestemt typesag, men også hvordan de ville dømme - alt andet lige - afhængig af om gerningspersonen var tidligere straffet eller ej, om gerningspersonen var en mand eller en kvinde, yngre eller ældre osv. Derfor har vi benyttet os af en teknik, hvor de ca. 3.000 mulige svarpersoner i hvert land i de gennemførte postenqueter ud fra et tilfældighedsprincip er blevet opdelt i mindre repræsentative udvalg, der så har fået forskellige variationer af den samme sag forelagt. F.eks. har den ene halvdel i røverisagen fået at vide, at gerningspersonen ikke tidligere har været straffet, mens 
den anden halvdel har fået ham beskrevet som en person, der er tidligere er dømt for røveri.

Herved er vi så sluppet for f.eks. at spørge folk direkte, om de ville straffe en mand hårdere end en kvinde, eller Mohammed strengere end Flemming - med stor risiko for at vi så blot ville få "politisk korrekte" svar. Nu kan vi i stedet sammenligne dem, der har taget stilling til sager, hvor gerningspersonen hedder Flemming, med dem, der har skullet tage stilling til sager, hvor gerningspersonen hedder Mohammed.

Fælles for postenqueterne og fokusgrupperne er det, at vi ved de forelagte sager ikke blot har spurgt befolkningen om, hvordan de selv ville dømme i disse sager. Vi har også spurgt befolkningen om, hvordan de tror domstolene ville dømme, og vi har spurgt befolkningen om, hvordan de tror, folk flest ville dømme.

\section{Norske resultater ${ }^{4}$}

Da det norske Stortinget vedtok siste del av den nye straffeloven i juni 2009, ble straffene skjerpet betydelig for voldspreget kriminalitet, herunder voldtekt og incest. Samtlige partier var enige i at dette var nødvendig - det var unison enighet om at det hastet med å bringe straffeutmålingen i domstolene på linje med det nye og høyere straffenivået det hadde vedtatt. Både det nye og høyere straffnivået - og hastverket med å få gjennomført det i praksis hvilte på en forutsetning om at det var i overensstemmelse med folks oppfatninger av det straffenivået som blir praktisert. I forarbeidene til lovendringene finnes det imidlertid ingen opplysninger om hvilke oppfatninger folk har om straff. Den enkle grunnen til dette er at det så godt som ikke finnes undersøkelser om dette. De undersøkelsene som ble gjennomført høsten 2009 kom for sent til å bli trukket inn i lovgivningsprosessen nevnt ovenfor. Likevel kan de kaste lys over spørsmålet om straffeskjerpingen var nødvendig for at straffenivået skulle være i overensstemmelse med folks rettsfølelse.

Telefonsurveyen viser at svært mange nordmenn er generelt kritiske til straffenivået. $68 \%$ svarte at de er enige i at straffene i Norge stort sett er for milde, 63 $\%$ gikk inn for lengre fengselsstraffer, $84 \%$ mente at voldsforbrytelser bør straffes langt hardere enn i dag, og drøyt halvdelen av de som ble intervjuet, sa seg enig i at å sitte i fengsel kan nesten betraktes som et hotellopphold. De innsatte har det alt for godt. Disse generelle oppfatningene kan umiddelbart synes å gi godt grunnlag for de straffeskjerpingene som ble vedtatt. En forutsetning for å tolke svarene i telefonsurveyen på denne måten er at folk har kjennskap til det reelle straffenivået. Både postsurveyen og fokusgruppeundersøkelsen gir mulighet til å undersøke om folk kjenner straffenivået. I begge undersøkelser kan vi sammenligne faktisk straffenivå i de seks sakene som inngikk i de norske undersøkelsene med den straff som folk tror at en domstol ville gitt. Sammenligningene viser at flertallet tror at 
domstolene bruker ubetinget fengsel sjeldnere enn de faktisk gjør, og at fengselsstraffene er kortere enn de faktisk er, jfr. diagram 3.0 som viser data for fokusgruppene. Det fremgår at folk gjennomgående undervurderer strengheten i de straffer som domstolene praktiserer. Undervurderingen av straffenivået er særlig utbredt når det gjelder straffenivået for typiske voldshandlinger som voldtekt, gatevold og partnervold. Av denne grunn gir ikke telefonsurveyen et godt grunnlag for å skjerpe straffene.

Diagram 3.0: Prosentandel av respondentene i fokusgruppene som tror at en domstol ville gitt ubetinget fengsel (antatt straffenivå), og som selv ville gitt denne straffen (foreslått straff). Veide tall.

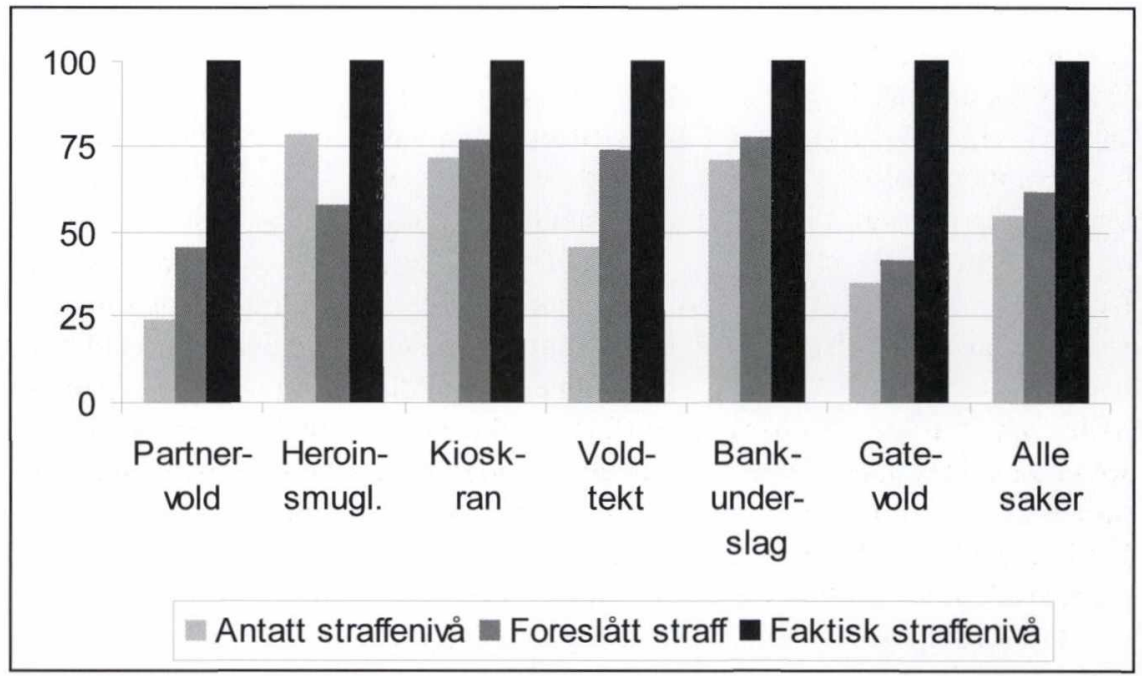

Soning med elektronisk fotlenke er inkludert i svarene.

Samtidig ble de spurte bedt om å angi hvilken straff de selv ville gitt for hver sak. Diagram 3.0 viser at de foreslåtte straffene er noe mer preget av ubetinget fengsels enn de antok at domstolene praktiserte i tre saker: gatevold, bankunderslag og kioskran. Klart flere foreslo ubetinget fengsel for voldtekt og partnervold enn de som trodde at en domstol ville gitt denne straffen. For heroinsmugling er forholdet omvendt. Færre foreslo selv ubetinget fengsel enn de som trodde at en domstol ville gitt denne straffen. - For samtlige lovbrudd var det imidlertid klart færre enn $100 \%$ som foreslo ubetinget fengsel som straff, som tilvarte straffenivået for alle saker. 
De som deltok i undersøkelsene og tok stilling til straff i de seks sakene, kunne krysse av for to reaksjoner. Dette er det tatt hensyn til i diagram 3.1. Det viser median straffverdi som er beregnet på grunnlag av en straffeskala ${ }^{5}$ der alle 31 svaralternativer som respondentene kunne velge å krysse av for, har fătt en tallverdi. I alle seks saker er antatt straffenivå (den straff folk tror at en domstol ville gitt) lavere enn faktisk straffenivå (dommerpanelets straff), og forskjellen er særlig stor for voldtekt, gatevold og partnervold. Det vil si at folk i særlig grad undervurderer det faktiske straffenivået for slik kriminalitet.

Diagram 3.1: Straffenivå, antatt straffenivå (den straff fokusgruppedeltakerne tror at en domstol ville gitt), og foreslått straff (den straff som de selv ville gitt) $i$ de seks sakene, angitt som median straffverdi. (Veide tall.)

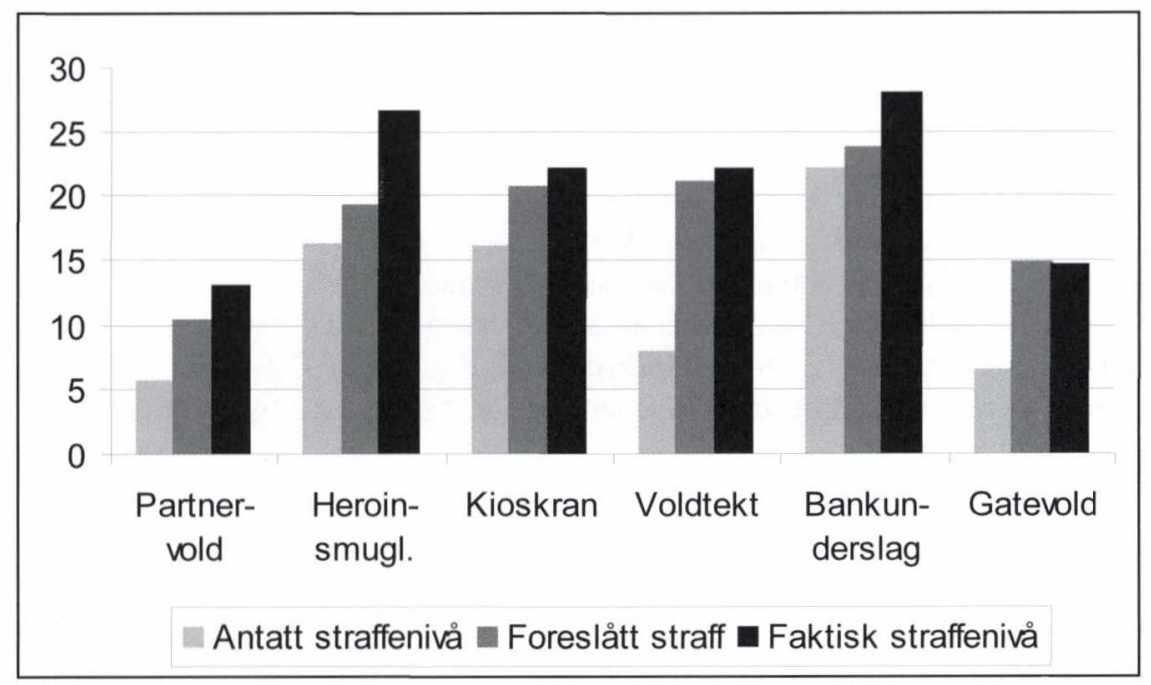

I tre av de seks sakene - kioskran, voldtekt og gatevold - er det meget godt samsvar mellom faktisk straffenivå og medianverdien for den straff som respondentene selv foreslo. Medianverdien for foreslått straff for partnervold er bare litt lavere enn straffenivået. For bankunderslag og heroinsmugling er det imidlertid en klart større forskjell mellom foreslått straff og faktisk straffenivå, og foreslått straff er lavere enn straffenivået. Et felles kjennetegn ved begge disse sakene er at faktisk straffenivå er høyt, ubetinget fengsel i flere år, men dette er mange nølende overfor. 
Denne undersøkelsen kan ikke underbygge at oppfatninger blant folk gjorde det nødvendig å skjerpe straffene for voldspreget kriminalitet. For det første viser undersøkelsen at det faktiske straffenivået blir undervurdert, og for det andre ønsker de spurte selv i gjennomsnitt ikke å gi straffer som er høyere enn straffenivået, men heller noe lavere straff i noen saker. Dermed ser det ut til at en sannsynlig og viktig forklaring på at mange i telefonintervjuene ga uttrykk for at straffene ikke er strenge nok, er at folk ikke har kjennskap til det faktiske straffenivå som blir praktisert av domstolene. Mange svarer at de ønsker strengere straffer fordi de undervurderer straffenivået, men det straffenivået de selv foreslår i konkrete saker, blir allerede praktisert. - Det finnes imidlertid to unntak fra dette: Straffenivået for heroinsmugling og bankunderslag ser ut til å være vesentlig høyere enn den straff mange selv ville gitt. Så her skulle det være rom for å senke straffenivået uten å komme i konflikt med folks konkrete rettsbevissthet.

\section{Svenske resultater 6}

För en generation sedan stod omsorgen om lagöverträdaren i centrum för kriminalpolitiken i Sverige. I dag är det i stället omsorgen om det allmänna rättsmedvetandet (Andersson 2002). Politiker och medier anser att domstolarna i allt mindre grad svarar med sådana straff som allmänheten kräver och därigenom inte tydligt visar den skada som centrala värden i samhället utsatts för.

Den ökande betydelse som det allmänna rättsmedvetandet tillmäts kan till del förstås mot bakgrund av den förändrade påföljdspolitiken. I Sverige har berättigandet av de straff domstolarna ska mäta ut tydligt förändrats sedan två årtionden. Detta framgår av den lagparagraf som styr domstolarnas dömande. Då Brottsbalken infördes 1965 var lagtexten följande (BrB. 1 kap., 7 par.):

Vid val av påföljd skall rätten, med iakttagande av vad som kräves för att upprätthålla allmän laglydnad, fästa särskilt avseende vid att påföljden skall vara ägnad att främja den dömdes anpassning i samhället.

År 1989 ersattes denna paragraf av en ny (BrB. 29 kap., 1 par.), där också ordet påföljd byttes ut mot straff:

Straff skall, med beaktande av intresset av en enhetlig rättstillämpning, bestämmas inom ramen för den tillämpliga straffskalan efter brottets eller den samlade brottslighetens straffvärde.

Denna förändring markerar en övergång från relativa till absoluta straff. Den innebär även en förändring $\mathrm{i}$ auktoriteten. Experten, som kriminologen och ämbets- 
mannen, kunde göra bedömningar och utvärderingar av allmänpreventiva och individualpreventiva effekter av olika påföljder. Experten har däremot inte någon särskild kompetens då det gäller att säga vad som är en korrekt dom eller lag $\mathrm{i}$ förhållande till moralisk klandervärdighet.

Här blir i stället politikern experten. Hon eller han är vald av folket och kan härigenom uttala vad det allmänna rättsmedvetandet kräver. Ett exempel på detta är när den svenska justitieministern våren 2010 presenterade en proposition (2009/10:14) för att höja straffen för allvarliga våldsbrott och som beräknas öka den svenska fångpopulationen med sju procent.

"Det finns en otålighet ute i det svenska samhället där man uppfattar att straffen för väldigt grova våldsbrott inte ligger $\mathrm{i}$ linje med den allmänna uppfattningen ... Den här skärpta synen som finns ute bland människor märks inte i domstolspraxis ... därför finns det starka skäl att höja straffnivån för de allvarligaste våldsbrotten" (Ask 2010).

Kriminologerna lämnas utanför kriminalpolitiken när det allmänna rättsmedvetandet blir grunden för denna politik. Vad kriminologerna dock kan göra är att undersöka detta allmänna rättsmedvetande. Detta har gjorts i Sverige med följande resultat. En utförligare redovisning har publicerats i form av en rapport (Jerre och Tham 2010).

Över hälften av de svarande i telefonundersökningen instämmer i påståenden om att straffen är för milda samt att straffen bör vara strängare och längre. Närmare 80 procent instämmer $\mathrm{i}$ att våldsbrott bör straffas mycket strängare än de görs idag. Enligt den generella inställningen till straff verkar alltså allmänheten missnöjd med straffnivån och efterlysa strängare och längre straff. Hur stabil är då denna uppfattning om de svarande själva får ikläda sig rollen som domare och efter att ha fătt mer information själva bestämma vad straffet bör bli i sex specifika fall?

Av dem som svarade på postenkäten ansåg en majoritet (60-80 procent) att straffet i samtlige fall borde bli fängelse. För narkotikabrottet, förskingringen och butiksrånet var det en lika stor andel som trodde att straffet i en domstol skulle bli fängelse. I våldtäkts-, gatuvålds- och relationsvåldsfallen var det dock en lägre andel som trodde att straffet skulle bli fängelse än som själva ansåg att fängelse borde dömas ut. De svarande ansåg sig alltså vilja ha strängare straff för tre av våldsbrotten än vad de trodde att straffet skulle bli i en domstol.

I fyra av fallen bedömde samtliga i domarpanelen, oavsett gärningspersonens tidigare kriminalitet eller missbruk, att påföljden skulle bli fängelse. I fallen med gatuvåld och relationsvåld resulterade två av domarbedömningarna i icke 
frihetsberövande påföljd. Domarpanelen angav alltså fängelse i högre grad än de svarande.

Utifrån en beräkning av fängelsestraffens snittlängd ${ }^{7}$ har de svarande dömt ut fler fängelsemånader än de trodde att en domstol skulle göra, framförallt $i$ våldtäktsfallet (figur 4.1). I jämförelse med domarpanelen har de svarande underskattat vad straffet skulle bli i en domstol. De har dessutom själva dömt ut färre fängelsemånader än domarna. Enligt den informerade inställningen till straff verkar alltså allmänheten inte vara för mycket strängare eller längre straff än vad som ges av domarna i de beskrivna fallen av narkotikabrott, förskingring, butiksrån, våldtäkt, gatuvåld och relationsvåld. I narkotikabrottsfallet är skillnaden mellan de svarandes och domarnas bedömningar påtaglig, i fallen med förskingring, butiksrån och gatuvåld är skillnaden mindre och $\mathrm{i}$ fallen med våldtäkt och relationsvåld är skillnaden obefintlig (figur 4.1).

Politikerna kritiserar domarna för att lägga sig i den nedre halvan av straffskalan och de uppmanas att i högre grad utnyttja den övre för att straffen skall hamna mer i linje med allmänhetens rättsmedvetande. De påföljder som tingsrättsdomarna angett här ligger mycket riktigt i den nedre halvan av straffskalan. Ett utnyttjande av den övre halvan skulle dock, i motsats till vad som hävdats, göra att skillnaden mellan praxis och allmänhetens inställning här snarare ökar än minskar.

Figur 4.1. Antal utdömda fängelsemånader (median) enligt domarpanelens bedömning samt enligt de svarande i postenkäten.

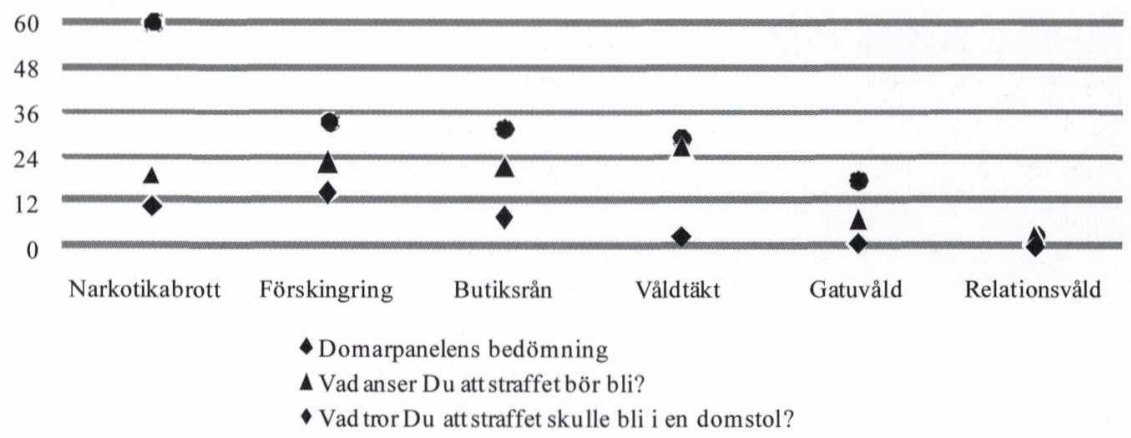

Av fokusgruppsdeltagarna var majoriteten initialt för fängelse som påföljd i de aktuella fallen. Efter filmvisning och diskussion ansåg endast hälften att straffet $i$ fallen med narkotikabrottet och butiksrånet borde bli fängelse, i fallen med våld- 
täkt och gatuvåld var det fortfarande något fler som valde fängelse än någon alternativ sanktionsform. Deltagarna dömde dock i genomsnitt ut kortare fängelsestraff efter att ha fått se rättegångsfilmen, fått mer information om olika sanktionsformer och sinsemellan diskuterat detta. Fokusgruppsdeltagarnas konkrete inställning till straff var alltså mildare än deras informerade inställning såsom det kom till uttryck i första respektive sista enkäten (figur 4.2).

Figur 4.2. Andel för strängare/längre straff än praxis/domarpanelen av de svarande i telefonintervju-, postenkät- respektive fokusgruppundersökningen.

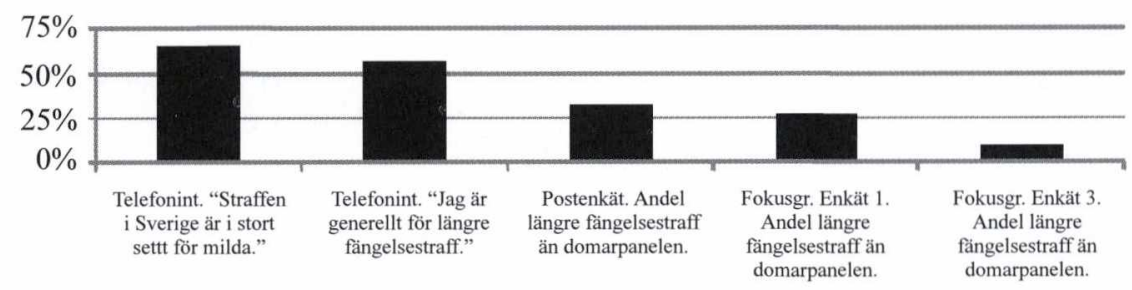

Hittills har analysen och redovisningen fokuserat på fängelse och längden på dessa straff. Majoriteten (cirka 70 procent) av dem som ansåg att fängelse borde dömas ut kombinerade detta med andra åtgärder, framförallt med behandling av gärningspersonen och ekonomisk kompensation till brottsoffret. Dessa två sanktioner dominerade också tydligt i den fjärdedel av de svarande som inte angav fängelse som straff.

Även om personerna i undersökningen i genomsnitt dömt ut färre fängelsemånader än tingsrättsdomarna innebär detta inte nödvändigtvis att de anser att straffet bör bli mindre omfattande eller ingripande. Det är möjligt att de svarande förespråkar ett tredelat straff. En del som gäller rättvisa och proportion vilket uttrycks genom fängelsestraffet, en annan del som gäller upprättelse av och hjälp till brottsoffret och en tredje del som gäller åtgärder för att gärningspersonen inte ska begå brott igen. "Strängare" straff behöver inte nödvändigtvis och endast handla om längre frihetsberövande utan om mer effektivitet utifrån en önskan om att straffet borde syfta till att ge positiva resultat för både gärningsperson och brottsoffer samtidigt som rättvisa skipas.

\section{Danske resultater ${ }^{8}$}

Som det er fremgået er de nordiske retsbevidsthedsundersøgelser i al væsentlighed metodisk en gentagelse af en undersøgelse, der blev gennemført i Danmark i 2006 (Balvig 2006). De skriftligt opsummerede sager og de filmede retssager drejede 
sig i 2006 om sager, hvor retspraksis i Danmark lå mellem 40 dages og 9 måneders ubetinget fængsel. I 2009-undersøgelserne har fokus været på sager, hvor retspraksis i Danmark er fra 1 års ubetinget fængsel til mere end 3 års ubetinget fængsel - et lidt eksotisk strafområde kan man måske mene, idet kun 1 ud af 10 ubetingede fængselsstraffe i Danmark er så lange, og vi kun taler om 2 promille af alle straffe i Danmark. På den anden side er der tale om uhørt stærke indgreb for dem, der udsættes for disse lange fængselsstraffe. For dem drejer det sig ikke om promiller, men om procenter af deres liv, som samfundet på denne måde fratager dem.

For Danmarks vedkommende finder vi i de undersøgelser, der nu er gennemført vedrørende meget alvorlige forbrydelser, præcis de samme tendenser, som vi fandt i 2006 for lidt mindre alvorlige forbrydelser - og vi finder de samme tendenser, som netop er beskrevet for Norge og Sveriges vedkommende - og i et efterfølgende afsnit vil blive beskrevet vedrørende Island.

Tabel 5.1. Befolkningens forestillinger om retspraksis i 8 forskellige skriftligt opsummerede sager, hvor gerningspersonen ikke er tidligere straffet.

\begin{tabular}{|c|c|c|c|c|c|c|c|c|}
\hline SAG: & $\begin{array}{l}\text { Partner- } \\
\text { vold }\end{array}$ & $\begin{array}{c}\text { Simpel } \\
\text { gade- } \\
\text { vold }\end{array}$ & $\begin{array}{l}\text { Salg af } \\
\text { narko }\end{array}$ & $\begin{array}{l}\text { Uagt- } \\
\text { somt } \\
\text { mand- } \\
\text { drab }\end{array}$ & $\begin{array}{l}\text { Alvor- } \\
\text { lig } \\
\text { gade- } \\
\text { vold }\end{array}$ & $\begin{array}{l}\text { Vold- } \\
\text { tægt }\end{array}$ & Røveri & $\begin{array}{l}\text { Smugl. } \\
\text { af narko }\end{array}$ \\
\hline $\begin{array}{l}\text { FAKTISK } \\
\text { RETSPRAKSIS: }\end{array}$ & $\begin{array}{l}40-60 \\
\text { dg. }\end{array}$ & $60 \mathrm{dg}$. & $80 \mathrm{dg}$. & $6 \mathrm{mdr}$. & 1 år & 1 år & $11 / 2$ år & $2-2 \frac{1}{2}$ år \\
\hline Ikke fængsel & 75 & 90 & 77 & 55 & 63 & 49 & 39 & 33 \\
\hline Kortere fængsel & \multirow{2}{*}{7} & \multirow{2}{*}{8} & 10 & 16 & 28 & 31 & 32 & 42 \\
\hline$=$ retspraksis & & & 6 & \multirow{2}{*}{29} & 6 & 11 & 14 & 14 \\
\hline Længere fængsel & 18 & 2 & 7 & & 3 & 9 & 15 & 11 \\
\hline I alt $\%$ & 100 & 100 & 100 & 100 & 100 & 100 & 100 & 100 \\
\hline
\end{tabular}


Tabel 5.2. Befolkningens holdning til, hvordan man selv ville dømme $i 8$ forskellige skriftligt opsummerede sager, hvor gerningspersonen ikke er tidligere straffet.

\begin{tabular}{|c|c|c|c|c|c|c|c|c|}
\hline SAG: & $\begin{array}{l}\text { Partner- } \\
\text { vold }\end{array}$ & $\begin{array}{c}\text { Simpel } \\
\text { gade- } \\
\text { vold }\end{array}$ & $\begin{array}{l}\text { Salg af } \\
\text { narko }\end{array}$ & $\begin{array}{c}\text { Uagt- } \\
\text { somt } \\
\text { mand- } \\
\text { drab }\end{array}$ & $\begin{array}{l}\text { Alvor- } \\
\text { lig } \\
\text { gade- } \\
\text { vold }\end{array}$ & $\begin{array}{l}\text { Vold- } \\
\text { tægt }\end{array}$ & Røveri & $\begin{array}{l}\text { Smugl. } \\
\text { af narko }\end{array}$ \\
\hline $\begin{array}{l}\text { FAKTISK } \\
\text { RETSPRAKSIS: }\end{array}$ & $\begin{array}{c}40-60 \\
\text { dg. }\end{array}$ & $60 \mathrm{dg}$. & $80 \mathrm{dg}$. & $6 \mathrm{mdr}$. & 1 år & 1 år & $11 / 2$ år & $2-2 \frac{1}{2}$ år \\
\hline Ikke fængsel & 53 & 79 & 64 & 41 & 48 & 34 & 32 & 40 \\
\hline Kortere fængsel & \multirow{2}{*}{9} & \multirow{2}{*}{9} & 8 & 15 & 27 & 22 & 21 & 32 \\
\hline$=$ retspraksis & & & 13 & \multirow{2}{*}{44} & 11 & 14 & 16 & 10 \\
\hline Længere fængsel & 38 & 12 & 15 & & 14 & 30 & 31 & 18 \\
\hline I alt $\%$ & 100 & 100 & 100 & 100 & 100 & 100 & 100 & 100 \\
\hline
\end{tabular}

Tabel 5.3. Befolkningens holdning til, hvordan man selv ville dømme $i 8$ forskellige retssager, hvor gerningspersonen ikke er tidligere straffet, vist på film med efterfølgende "votering".

\begin{tabular}{|c|c|c|c|c|c|c|c|c|}
\hline SAG: & $\begin{array}{l}\text { Partner- } \\
\text { vold }\end{array}$ & $\begin{array}{c}\text { Simpel } \\
\text { gade- } \\
\text { vold }\end{array}$ & $\begin{array}{c}\text { Salg af } \\
\text { narko }\end{array}$ & $\begin{array}{l}\text { Uagt- } \\
\text { somt } \\
\text { mand- } \\
\text { drab }\end{array}$ & $\begin{array}{l}\text { Alvor- } \\
\text { lig } \\
\text { gade- } \\
\text { vold }\end{array}$ & $\begin{array}{l}\text { Vold- } \\
\text { tægt }\end{array}$ & Røveri & $\begin{array}{l}\text { Smugl. } \\
\text { af narko }\end{array}$ \\
\hline $\begin{array}{l}\text { FAKTISK } \\
\text { RETSPRAKSIS: }\end{array}$ & $\begin{array}{l}40-60 \\
\text { dg. }\end{array}$ & $60 \mathrm{dg}$. & $80 \mathrm{dg}$. & $6 \mathrm{mdr}$. & 1 år & 1 år & $11 / 2$ år & $2-2 \frac{1}{2}$ år \\
\hline Ikke fængsel & 89 & 94 & 88 & 57 & 58 & 64 & 72 & 69 \\
\hline Kortere fængsel & \multirow{2}{*}{11} & \multirow{2}{*}{3} & 4 & 0 & 32 & 24 & 21 & 15 \\
\hline$=$ retspraksis & & & 4 & \multirow{2}{*}{43} & 7 & 9 & 0 & 13 \\
\hline Længere fængsel & 0 & 3 & 4 & & 3 & 3 & 7 & 3 \\
\hline I alt $\%$ & 100 & 100 & 100 & 100 & 100 & 100 & 100 & 100 \\
\hline
\end{tabular}

For at minimere gentagelser skal der derfor her alene i ukommenteret tabelform gengives hovedresultaterne for de væsentligste dele af de danske undersøgelser i 2006 og 2009 - jf. tabel 5.1, 5.2 og 5.39 - suppleret med ét uddybende eksempel, sagen om alvorlig gadevold:

En sen aften overfalder en mand en anden mand udenfor en grillbar. Den overfaldne er fuldstcendig sagesløs. Han bliver slået på med knyttede naver. Han bliver også slået $i$ hovedet med en colaflaske, der knuses. Da manden 
falder om på jorden, bliver han forst sparket $i$ ansigtet og dernoest trampet på den ene side af hovedet. Udover forskellige behandlingskrcevende sår fär den overfaldne brakket sin noese, brakket et kindben og pådrager sig en hjernerystelse m.v.

Ifølge dommerpanelerne er retspraksis i de nordiske lande i en sag som denne noget forskellig. I Danmark ville dommen i en retssag for en hidtil ustraffet person i 2010 være 1 års ubetinget fængsel. Det ville den også i Sverige, måske lidt strengere. I Norge og Island ville dommen være mildere i form af en kortere ubetinget frihedsstraf, mens det for Finlands vedkommende er tvivlsomt, om der ville blive tale om en ubetinget frihedsstraf i det hele taget.

Adskillige undersøgelser viser, at næsten alle danskerne har en generel holdning til, hvordan de synes, der bør straffes for vold. Dette viser sig imidlertid at stå i stærk kontrast til, hvad danskerne ved om, hvordan der straffes. I sagen om alvorlig gadevold var det eksempelvis kun 6 pet., der havde den korrekte opfattelse, at en sådan sag ville koste omkring 1 års ubetinget fængsel, jf. tabel 5.1. 3 pct. mente, at der ville blive tale om en længere ubetinget frihedsstraf. Hele 63 pct. - altså op mod 2 ud af 3 - var af den opfattelse, at de danske domstole ville idømme en betinget dom, eller i hvert fald ikke en ubetinget fængselsstraf.

I deres faktiske uvidenhed om, hvordan der straffes, skyder danskerne ikke blot med spredehagl i deres forsøg på at gætte strafniveauet; der er tillige en tydelig tendens i forestillingerne. Danskerne undervurderer således i markant grad domstolenes strenghed. I tæt ved to årtier har de danskere politikere over en bred kam talt meget om vigtigheden af at udsende klare, utvetydige og kraftige signaler gennem at skærpe straffene og derved få et højt straffeniveau for vold domineret af relativt lange frihedsstraffe. Og det er ikke blevet ved ordene. Adskillige gange er der vedtaget betydelige strafskærpelser, især for personfarlig kriminalitet. Det er imidlertid næppe forkert at konkludere, at denne kriminalpolitiske signaltjeneste ikke har fungeret. Signalerne er blevet udsendt, men de er ikke nået frem til eller er blevet opfattet eller forstået af majoriteten af den danske befolkning.

På det generelle plan, præget af uvidenhed om de faktiske forhold som den er, har danskerne ikke blot en mening om straffene for vold. Den generelle mening går tillige markant i én bestemt retning: Ifølge de i 2010 gennemførte telefonsurveys var det 3 ud af 4 , der mente, at man burde straffe langt hårdere for vold. På sin vis er der da også overensstemmelse mellem denne generelle holdning på den ene side, og så hvordan man vil dømme i eksempelvis den konkrete sag om gadevold på den anden, jf. tabel 5.2 og 5.3 sammenholdt med tabel 5.1. Tendensen går i retning af, at man vil dømme strengere i denne konkrete sag, end man tror domstolene ville dømme. 
Billedet er helt anderledes, hvis egne holdninger (tabel 5.2 og 5.3) sammenholdes med den faktiske retspraksis. Bedømmer man på basis af skriftligt opsummerede sager, er det 3 ud af 4 danskere, der ville dømme mildere end domstolene, og sker det på basis af en filmet retssag med efterfølgende diskussion ("votering"), er det hele 9 ud af 10. I sidstnævnte situation, der jo er den, der i information og nærhed mest ligner den situation faktisk at skulle dømme i en retssag, f.eks. som lægdommer, er det et flertal - 58 pct. - der ikke ville idømme en ubetinget frihedsstraf overhovedet i sagen om alvorlig gadevold. Af tabel 5.3 fremgår det, at dette ikke alene gælder holdningerne til, hvordan man ville dømme i en sag om alvorlig gadevold. I samtlige 8 sager, hvor den faktiske retspraksis strækker sig fra 40 dage til 2-21/2 år, er det et flertal, der ikke ville idømme ubetinget fængselsstraf.

Som eksemplet om gadevold illustrerer, er hovedkonklusionerne for de danske undersøgelser i 2006 og 2009 da, at danskerne i relativt alvorlige sager om personfarlig kriminalitet mv. ikke har nogen anelse om, hvordan der faktisk straffes, at man markant undervurderer strengheden i den faktiske retspraksis, og at man til trods for, at man generelt mener, at straffene burdes skærpes, er betydeligt mere tilbageholdne over for at bruge fængselsstraf i konkrete sager end domstolene er. I tillæg hertil viser de nærmere analyser bl.a.,

- at hvor danskerne på den ene side har en tendens til at se sig selv som strengere end domstolene, så ser de sig som mildere end folk flest

- at hovedtendenserne gør sig gældende uanset om gerningspersonen er tidligere straffet eller ej, har sociale problemer/misbrugsproblemer eller ej eller er ung eller ældre.

- at den eneste undtagelse fra hovedtendenserne umiddelbart synes at være holdningerne til visse sædelighedsforbrydelser, hvor hovedparten af danskerne i visse (men ikke alle) situationer er ligeså strenge som domstolene

- at danskerne gennemgående rangordner sagerne efter deres alvorlighedsgrad på samme måde som domstolene. Bemærkelsesværdigt er det her bl.a., at danskerne - som domstolene - rangerer alvorlig økonomisk kriminalitet på niveau med alvorlig personfarlig kriminalitet

- at holdningerne til, hvordan man synes, der bør dømmes i narkotikasager, indtager en særstilling derved, at danskerne her ikke blot reelt er betydeligt mildere i deres domme end domstolene; man har i modsætning til ved andre sager tillige selv en oplevelse af, at man er mildere. Dette er en klar indikation på, at i særdeleshed på dette område er det faktiske straffeniveau ude af trit med og i betydeligt omfang overskrider, hvad de fleste danskere synes er ret og rimeligt. Det er interessant, at tilsvarende tendenser øjensynligt gør sig gældende i flere af de andre nordiske lande. 
De gennemførte undersøgelser rejser to helt centrale kriminalpolitiske spørgsmål. For det første rejser de spørgsmålet om, hvordan man får signaltjenesten på det strafferetlige område til at virke: Hvordan får man danskerne orienteret om, hvordan der faktisk straffes for alvorlig kriminalitet, og hvornår og hvordan især fængselsstraffen bruges. For det andet rejser undersøgelserne spørgsmålet om, hvordan man kan mindske brugen af fængselsstraf og gøre de anvendte fængselsstraffe kortere, således at man ikke i det strafferetlige system så massivt og nærmest systematisk, som tilfældet er, overskrider, hvad majoriteten i den danske befolkning finder ret og rimeligt.

\section{Islandske resultater ${ }^{10}$}

I de sidste år har vi fået længere fængselsdomme i Island, ikke mindst i sager om vold og seksuelle overgreb, men også i narkotikasager (Fængselsomsorgen, 2010). Vi har et voksende antal fanger i Island, og flere hundrede dømte venter på ledig fængselsplads for at kunne afsone deres dom ("Mangel på fængsler", 2009). Omkring en tredjedel flere bliver dømt til fængsel i Island i dag end for ti år siden, og andelen, som får længere domme end tolv måneder, er nu omkring en tredjedel større end dengang. De lange straffe udgør nu 16 pct. af alle fængselsdomme, men det var 12 pct. for ti år siden. Dette skyldes kun delvis et voksende antal lovovertrædelser, årsagen er hovedsageligt en hårdere straffepolitik, som ofte bliver retfærdiggjort ved at henvise til den offentlige opinion.

Der er en tilsvarende udvikling i mange andre lande, også i Norden. Antallet af fanger vokser, og straffene bliver hårdere. Det virker ikke som om, den hårdere retspraksis spiller stor rolle for befolkningens forhold til straf. Et eksempel er USA, hvor man både har dødsstraf og udmåling af flere livstidsdomme ad gangen, men alligevel kræver befolkningen hårdere straffe (Kury og Ferdinand, 2008).

For så vidt angår Island, viser opinionsundersøgelser, at de fleste i befolkningen mener, at straffene er for milde (75 pct.), og at fanger har det for godt (53 pct.). Dette bliver bekræftet i vores telefoninterviews om de generelle holdninger til forbrydelser og straf. Billedet er det samme som i det øvrige Norden.

Men hvis islændingene selv sidder i dommersædet og modtager flere oplysninger om de enkelte forbrydelser, bliver de mindre straffeglade (se diagram). 
Diagram 6.0. Informeret holdning til strafi Island: Andel, som angav ubetinget faengelse i postspørgeskemaundersøgelsen samt dommerpanelets vurdering (prosent).

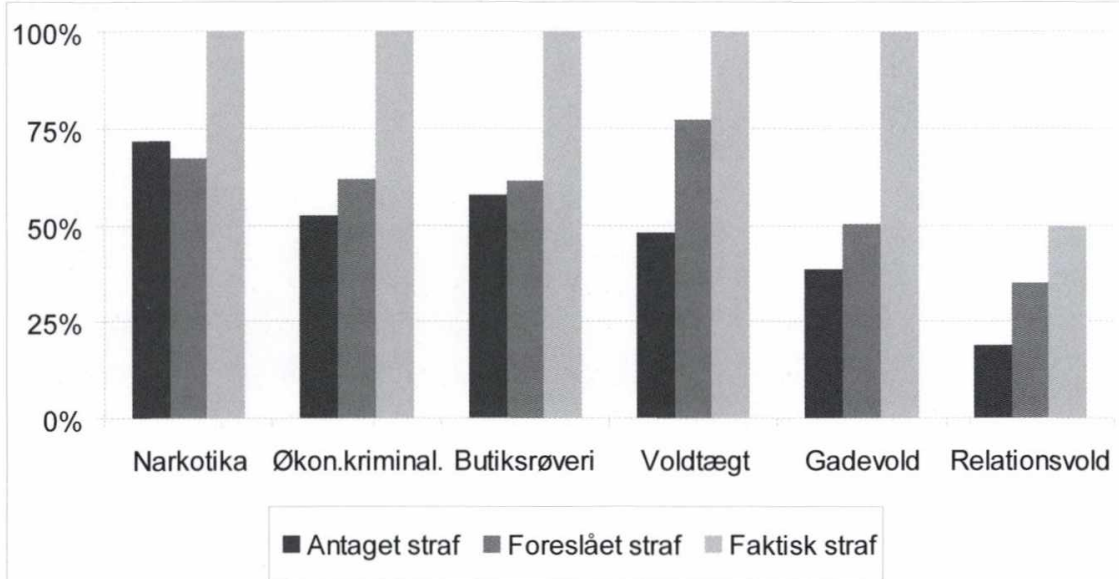

Samtidig ønsker befolkningen større variationer i mulige straffealternativer end kun længden af et fængselsophold. Det er specielt tydeligt, hvor meget mindre straffeglade man bliver som følge af øget information og drøftelse om forbrydelsen i fokusgrupperne. Både postspørgeskemaundersøgelsen og fokusgrupperne viste også, at islændingene har en tendens til at undervurdere, hvor hårde straffe domstolene faktisk idømmer. Strafudmålingen i det islandske retsvæsen blev i overvejende grad vurderet til at være mildere, end retspraksis faktisk er. Det viste sig endvidere, at det, de fleste islændinge mente var passende straf, i overvejende grad var mildere end retspraksis tilsiger - ligesom tilfældet var i de øvrige nordiske lande.

Det findes en vigtig undtagelse i postspørgeskemaundersøgelsen. Den angår holdningen til straf for smugling af narkotika. Mange af dem, der svarede, ønskede en mildere straf, end de mente, retsvæsenet ville udmåle. Et andet interessant resultat findes i holdningen til straf for voldtægt. Mange af dem, der svarede, mente, at domstolene er meget mildere, end de selv ville være, og denne forskel mellem antaget $\mathrm{og}$ foreslået straf er større end for de andre lovovertrædelser. Dette betyder endvidere, at befolkningen med hensyn til deres egen vurdering af en passende straf for voldtægt ligger nærmest domstolenes vurdering i sagen om voldtægt. Sandsynligvis afspejler dette samfundsdebatten om, at domstolene er alt for milde i sager om seksualforbrydelser - selv om det faktisk ikke viser sig i vores undersøgelse. 
Man kan naturligvis spørge sig, om befolkningen overhovedet skal blande sig i diskussion om straffeudmåling, eller om det udelukkende skal foregå gennem lovgiveren og i retsvæsenet, hvor de faglige kundskaber findes. Dette kan være et acceptabelt standpunkt, men befolkningens retssikkerhed vil dog sandsynligvis øge med offentlighedens støtte til retsstaten. Lovgiver og retsvæsen i opposition til befolkningen vil nok aldrig hvile på et solidt underlag. Meget tyder på, at det, vi kalder folkeviljen, har været brugt til at retfærdiggøre de sidste års stadig hårdere politik med hensyn til strafudmålingen (se f. eks. Morgunblaðið, 2007). Vores undersøgelse indikerer, at det slet ikke er sikkert, at denne vilje er tolket rigtigt.

Konklusionerne er, at borgerne undervurderer, hvor hårdt retsvæsenet faktisk straffer for lovovertrædelser - noget der blev tydeliggjort i alle straffesagerne i den islandske undersøgelse. Alligevel er det helt tydeligt, at befolkningen ønsker, at lovovertræderne skal undgælde for deres forbrydelser - men på mere varieret måde end den, vi generelt har set i Island. Det skal i højere grad ske som f.eks. $ø$ konomisk kompensation til offeret, bøder, mægling, fodlænker og/eller behandling. Befolkningen ønsker ikke automatisk udelukkende længere fængselsstraffe som løsning på kriminalitet, men mener tværtimod, at der findes mange flere strafalternativer end dem, man benytter i dag.

Vi håber at denne undersøgelse vil give anledning til en saglig samfundsdebat om forbrydelser og straf. Retsvæsenet og specialister på området burde være forpligtigede til at forklare for borgerne, hvordan retsvæsenet behandler straffesager, ikke nødvendigvis på grundlag af bestemte domme, men snarere i lys af generel retspraksis og retsfilosofi. Det er vigtigt at informere befolkningen om både retsvæsenets betydning og begrænsninger. Både loven og retspraksis bør genspejle borgernes retsbevidsthed, og derfor er det nødvendigt, at man også forsøger at forme denne bevidsthed gennem saglig information og fortælle befolkningen om de retslige reaktioner og deres forudsætninger. Vores undersøgelse tyder på, at der er et stort behov for dette, og det er det vigtigt at lytte til.

\section{Litteratur}

Andersson, Robert, 2002. Kriminalpolitikens väsen. Stockholm: Stockholms universitet, Kriminologiska institutionen.

Ask, Beatrice, 2010. "Skärpta straff för våldsbrott" . Presskonferens 28 januari 2010. http://www.regeringen.se/sb/d/12609/a/138609.

Balvig, Flemming (2006a). Danskernes syn på straf. København: Advokatsamfundet.

Balvig, Flemming (2006b). Metodisk redegørelse for undersøgelsen af danskernes syn på straf. København: Advokatsamfundet. 
Balvig, Flemming (2010a). Danskernes retsfølelse og retsfornuft - et forspil. København: Det Juridiske Fakultet, Københavns Universitet.

Balvig, Flemming (2010b). "Danskernes retsfornuft", Advokaten, 9. november.

Fængselsomsorgen (Fangelsismálastofnun), (2010). Ársskýrslur (Årsrapporter). Sjá www.fangelsi.is. Hented 31. august, 2010.

Jerre, Kristina och Tham, Henrik, 2010. Svenskarnas syn på straff. Rapport 2010:1. Stockholm: Stockholms universitet, Kriminologiska institutionen. Tillgänglig på Internet, www.criminology.su.se.

Kury, H. og Ferdinand, T. N. (2008). International Perspectives on Punitivity. Bochum: Universitets forlaget Dr. N. Brockmeyer.

Morgunblaðið, (2007). "Hæstiréttur og kynferðisbrot" (Höjeste Ret og sexual brott). 15. september, 2007: 28.

Olaussen, L. P (2010): Straffenivået og folks holdninger til straff $i$ Norge. Rapport. Institutt for kriminologi og rettssosiologi, UiO. http://www.jus.uio.no/ $\mathrm{ikrs/forskning/prosjekter/holdningertilstraff/Olaussen \% 20rapporten/olaussen-}$ rapporten.html

Proposition 2009/10:14. Skärpta straff för allvarliga våldsbrott m.m. Stockholm: Justitiedepartementet.

"Skortur á fangelsum" (Mangel på fængsler), (2009). http://www.visir.is/article/2009870959678 Visir.is, 20. september, 2009. Hentet 17. august 2010.

\section{Noter:}

1 Skrevet av Flemming Balvig.

2 Det Juridiske Fakultets Moot Court, Københavns Universitet.

3 For Danmarks vedkommende indgik der i 2009 endvidere en sag omhandlende pædofili.

4 Skrevet av Leif Petter Olaussen.

5 Se Olaussen (2010) s. 39-41. Jeg gjør oppmerksom på at straffeskalaen som jeg anvender, avviker fra den Flemming Balvig har anvendt $\mathrm{i}$ analyser av det danske materialet.

6 Skrevet av Kristina Jerre og Henrik Tham.

7 Medianlängd där icke-frihetsberövande påföljd räknas som noll fängelsemånader.

8 Skrevet av Flemming Balvig.

9 Sagerne her er alene de i alt 8 sager (4 i 2006 og 4 i 2009), hvor den danske befolknings holdning til, hvordan der burde straffes, er belyst i såvel postenqueter og fokusgrupper. Se vedrørende de øvrige sager Balvig 2006 og Balvig 2010.

10 Skrevet av Helgi Gunnlaugsson.

E-postadresser:

Flemming Balvig, e-mail: flemming.balvig@jur.ku.dk Helgi Gunnlaugsson, e-mail: helgigun@hi.id

Kritina Jerre, e-mail: kristina.jerre@criminology.su.se Leif Petter Olaussen, e-mail: lp.olaussen@jub.vid.no Henrik Tham, e-mail henrik.tham@criminology.su.se 